\title{
18. Exploring the Role of Life Scientists in Combating the Misuse of Incapacitating Chemical and Toxin Agents
}

\author{
Michael Crowley
}

\section{Introduction}

Over the past two decades there has been a revolution in the life sciences with extremely rapid advances in genomics, synthetic biology, biotechnology, neuroscience and the understanding of human behaviour. The speed of progress is staggering. For example, in 1999 a special meeting of the National Academies of Sciences and the Society of Neuroscience noted that ' $[\mathrm{t}]$ he past decade had delivered more advances than all previous years of neuroscience research combined'. ${ }^{1}$ Many of these developments have great potential to benefit humankind - in, for example, the production of more effective, safer medicines. ${ }^{2}$ Concern has been raised, however, by a growing number of those in the scientific and medical communities regarding the 'dual-use' nature of certain advances with the consequent danger of the new technologies being misused for the development of a new range of chemical or biological weapons. Meselson has stated that '[d]uring the century ahead, as our ability to modify fundamental life processes continues its rapid advance, we will be able not only to devise additional ways to destroy life, but also be able to manipulate it including the processes of cognition, development and inheritance'. ${ }^{3}$

And he added: 'A world in which these capabilities are widely employed for hostile purposes would be a world in which the very nature of conflict had radically changed. Therein could lie unprecedented opportunities for violence, coercion, repression or subjugation. ${ }^{4}$

\footnotetext{
1 Society of Neuroscience 1999, Neuroscience 2000: A New Era of Discovery, Symposium organised by the Society of Neuroscience, Washington, DC, 12-13 April.

2 Andreasen, N. 2004, Brave New Brain: Conquering Mental Illness in the Era of the Genome, Oxford University Press, USA.

3 Meselson, M. 2000, 'Averting the hostile exploitation of biotechnology', The CBW Conventions Bulletin, no. 48 , pp. $16-19$.

4 Ibid., pp. 16-19.
} 
On the Dual Uses of Science and Ethics

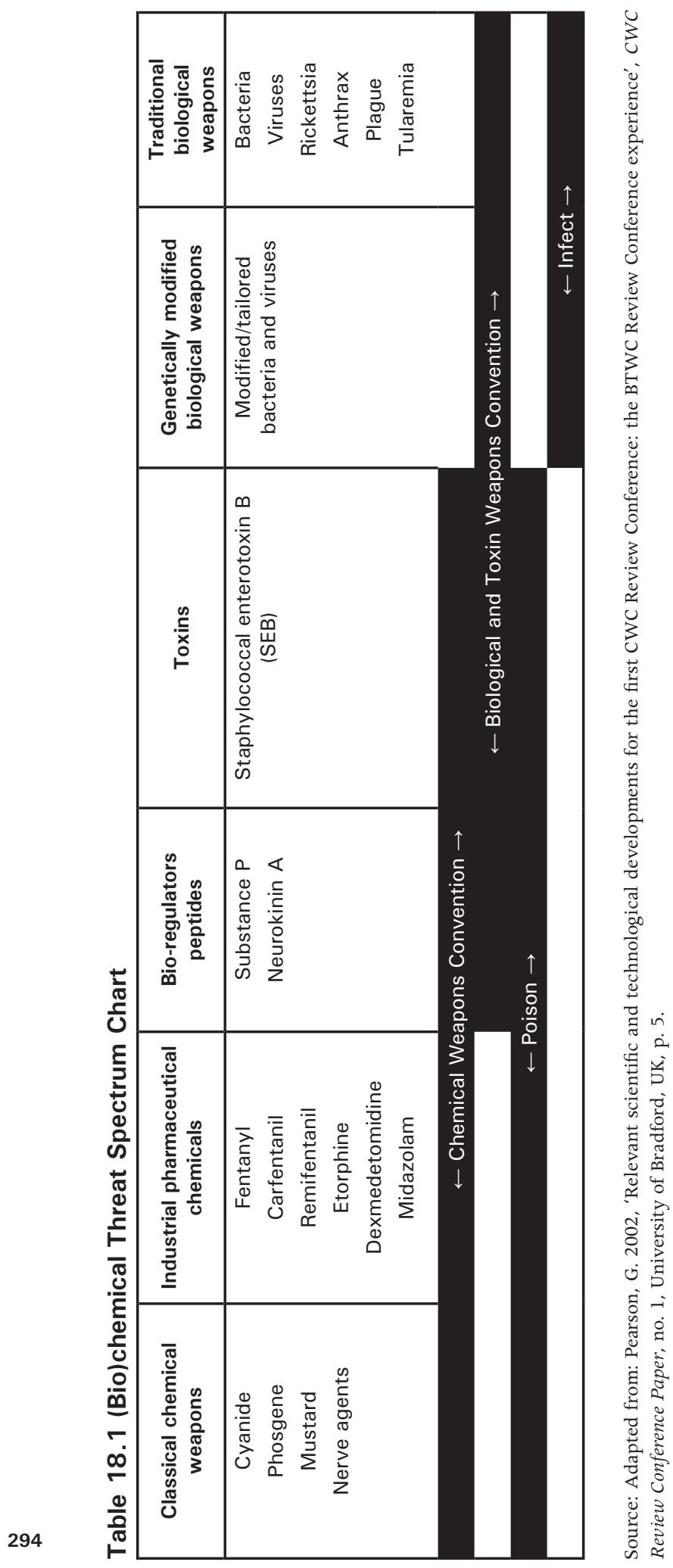


As the ongoing revolution in the life sciences has proceeded, the boundary between chemistry and biology, and consequently the distinction between certain chemical and biological weapons, has become increasingly blurred. Rather than thinking of chemical and biological weapons threats as distinct, certain analysts including Aas, ${ }^{5}$ Dando, ${ }^{6}$ Davison $^{7}$ and Pearson ${ }^{8}$ believe it is more useful to conceptualise them as lying along a continuous biochemical threat spectrum. This chapter will focus upon research and development of those midspectrum agents (pharmaceutical chemicals, bio-regulators and toxins featured in Table 18.1) that some consider as having potential utility as incapacitating weapons (incapacitants). The chapter will employ a holistic arms control (HAC) approach to examine the potential dangers and proposed utility of such agents and explore the obligations and opportunities for the life-science community to ensure that such agents are not utilised for hostile purposes.

\section{Incapacitants: A primer}

Although certain states and multilateral organisations such as the North Atlantic Treaty Organisation (NATO) ${ }^{9}$ have sought to characterise incapacitants, there is currently no internationally accepted definition for these chemical agents. Indeed certain leading international experts believe that such a technical definition is not possible. ${ }^{10}$ Whilst recognising the contested nature of this discourse, as a provisional working description, they can be considered as substances whose chemical action on specific biochemical processes and physiological systems, especially those affecting the higher regulatory activity of the central nervous

\footnotetext{
5 Aas, P. 2003, 'The threat of mid-spectrum chemical warfare agents', Prehospital and Disaster Medicine, vol. 18, no. 4, pp. 306-12.

6 Dando, M. 2007, 'Scientific outlook for the development of incapacitants', in A. Pearson, M. Chevrier and M. Wheelis (eds), Incapacitating Biochemical Weapons, Lexington Books, Lanham, Md, p. 125.

7 Davison, N. 2009, Non-Lethal Weapons, Palgrave Macmillan, Basingstoke, UK, pp. 106-7.

8 Pearson, op. cit.

9 NATO defines an incapacitant as a 'chemical agent which produces temporary disabling conditions which (unlike those caused by riot control agents) can be physical or mental and persist for hours or days after exposure to the agent has ceased. Medical treatment, while not usually required, facilitates a more rapid recovery.' North Atlantic Treaty Organisation (NATO) 2000, Glossary of Terms and Definitions (AAP-6 (V), Modified version 02), 7 August 2000.

10 A report of an expert meeting organised by Spiez Laboratory concluded that 'because there is no clearcut line between (non-lethal) ICA [incapacitating chemical agents] and more lethal chemical war-fare agents, a scientifically meaningful definition cannot easily be made. One can describe several toxicological effects that could be used to "incapacitate", but in principle there is no way to draw a line between ICAs and lethal agents.' See Mogl, S. (ed.) 2011, Technical Workshop on Incapacitating Chemical Agents, Spiez, Switzerland, 8-9 September; Spiez Laboratory 2012, op cit., p. 10; The Royal Society 2012, Brain Waves Module 3: Neuroscience, Conflict and Security, Science Policy Centre, The Royal Society, London, pp. 44-5; Organisation for the Prohibition of Chemical Weapons (OPCW) 2013, Report of the Scientific Advisory Board on Developments in Science and Technology for the Third Special Session of the Conference of the States Parties to the Chemical Weapons Convention, Third Review Conference RC-3/DG.1, 8-19 April 2013, 29 October 2013, p. 4.
} 
system, produce a disabling condition (for example, can cause incapacitation or disorientation, incoherence, hallucination, sedation or loss of consciousness) or, at higher concentrations, death. ${ }^{11}$

There is a wide variety of agents that could potentially be utilised as incapacitants including anaesthetic agents, skeletal muscle relaxants, opioid analgesics, anxiolytics, antipsychotics, antidepressants and sedative-hypnotic agents, ${ }^{12}$ many of which are currently legitimately utilised by the medical or veterinary professions. ${ }^{13}$ Table 18.2 summarises the results of a literature study and analysis of biomedical research into a range of pharmaceutical agents, published in 2000, by the Applied Research Laboratory and the College of Medicine at Pennsylvania State University, to identify the range of drug classes that had potential utility as incapacitants. The study clearly illustrates and indeed actively explores the potential dual-use applications of drugs initially developed for medical purposes, noting that:

It is well known that for every one new compound successfully proceeding from the discovery phase through all phases of clinical trials and on to market, perhaps hundreds, if not thousands, of compounds are discarded or shelved by the pharmaceutical industry [for example, as a result of their side effects] ... However, in the variety of situations in which non-lethal techniques are used there may be less need to be concerned with side-effects; indeed, perhaps a calmative may be designed that incorporates a less than desirable side-effect ... as part of the drug profile. ${ }^{14}$

Furthermore, the study recommends explicit collaboration in this area, stating that it may be appropriate to develop a working relationship with the pharmaceutical industry to better incorporate their knowledge and expertise in developing a non-lethal calmative technique'.${ }^{15}$ The ethical implications of such relationships are, however, not explored.

\footnotetext{
11 Adapted from Pearson et al., op. cit., p. xii. Incapacitants have also been called advanced riot-control agents, biochemical agents, biotechnical agents, calmatives, incapacitating biochemical weapons and immobilising agents.

12 See, for example: Lakoski, J., Bosseau Murray, W. and Kenny, J. 2000, The Advantages and Limitations of Calmatives for Use As A Non-Lethal Technique, College of Medicine Applied Research Laboratory, Pennsylvania State University.

13 See Aas, op. cit., p. 309

14 Lakoski et al., op. cit., p. 48.

15 Ibid., p. 48.
} 
18. Exploring the Role of Life Scientists in Combating the Misuse of Incapacitating Chemical and Toxin Agents

\section{Figure 18.2 Indicative Drug Classes and Agents with Potential Utility as Incapacitants}

\begin{tabular}{|c|c|c|}
\hline Drug class & Selected compounds & Site of action \\
\hline Benzodiazepines & $\begin{array}{l}\text { Diazepam } \\
\text { Midazolam } \\
\text { Etizolam } \\
\text { Flumazenil (antagonist) }\end{array}$ & GABA receptors \\
\hline $\begin{array}{l}\text { Alpha }{ }_{2} \text { adrenergic receptor } \\
\text { agonists }\end{array}$ & $\begin{array}{l}\text { Clonidine } \\
\text { Dexmedetomidine } \\
\text { Fluparoxan (antagonist) }\end{array}$ & $\begin{array}{l}\text { Alpha }{ }_{2} \text { adrenergic } \\
\text { receptors }\end{array}$ \\
\hline Dopamine D3 receptor agonists & $\begin{array}{l}\text { Pramipexole } \\
\text { Cl-1007 } \\
\text { PD } 128907\end{array}$ & D3 receptors \\
\hline $\begin{array}{l}\text { Selective serotonin reuptake } \\
\text { inhibitors }\end{array}$ & $\begin{array}{l}\text { Fluoxetine } \\
\text { Sertraline } \\
\text { Paroxetine } \\
\text { WO-09500194 }\end{array}$ & 5-HT transporter \\
\hline $\begin{array}{l}\text { Serotonin } 5-\mathrm{HT}_{1 \mathrm{~A}} \text { receptor } \\
\text { agonists }\end{array}$ & $\begin{array}{l}\text { Buspirone } \\
\text { Lesopitron } \\
\text { Alnespirone } \\
\text { MCK-242 } \\
\text { Oleamide } \\
\text { WAY-100, } 635\end{array}$ & $5-\mathrm{HT}_{1 \mathrm{~A}}$ receptor \\
\hline Opioid receptors and mu agonists & $\begin{array}{l}\text { Morphine } \\
\text { Carfentanil } \\
\text { Naloxone (antagonist) }\end{array}$ & Mu opioid reception \\
\hline Neurolept anaesthetics & $\begin{array}{l}\text { Propofol } \\
\text { Droperidol and fentanyl } \\
\text { combination } \\
\text { Phencyclidines }\end{array}$ & $\begin{array}{l}\text { GABA receptors } \\
\text { DA, NE and GABA } \\
\text { receptors } \\
\text { Opioid receptors }\end{array}$ \\
\hline $\begin{array}{l}\text { Corticotrophin-releasing factor } \\
\text { receptor antagonists }\end{array}$ & $\begin{array}{l}\text { CP 154,526 (antagonist) } \\
\text { NBI } 27914 \text { (antagonist) } \\
\text { CRF-BP (binding protein) }\end{array}$ & CRF receptor \\
\hline $\begin{array}{l}\text { Cholecystokinin B receptor } \\
\text { antagonists }\end{array}$ & $\begin{array}{l}\text { CCK-4 } \\
\text { Cl-988 (antagonist) } \\
\text { Cl-1015 (antagonist) }\end{array}$ & CCKB receptor \\
\hline
\end{tabular}

Source: Adapted from Lakoski, J., Bosseau Murray, W. and Kenny, J. 2000, The Advantages and Limitations of Calmatives for Use As A Non-Lethal Technique, College of Medicine Applied Research Laboratory, Pennsylvania State University, pp. 15-16. 
There is a long history, dating from the late 1940s, of certain state programs attempting to develop incapacitant weapons employing a range of pharmaceutical chemicals or toxins. ${ }^{16}$ Analysis of open-source information from the mid 1990s onwards indicates that a number of states including China, ${ }^{17}$ the Czech Republic, ${ }^{18}$ Russia $^{19}$ and the United States ${ }^{20}$ appear to have conducted research relating to incapacitants and/or possible means of delivery at some stage during this period. It is, however, difficult to establish the current situation, and certain states that have previously shown an interest in developing such agents - such as the United States - have recently declared that no such activities currently take $_{\text {place. }}{ }^{21}$

According to the International Committee of the Red Cross (ICRC): "There is clearly an ongoing attraction to "incapacitating chemical agents" but it is not easy to determine the extent to which this has moved along the spectrum from academia and industrial circles into the law enforcement, security and military apparatuses of states.' ${ }^{22}$

16 See, for example: Crowley, M. 2009, Dangerous Ambiguities: Regulation of Riot Control Agents and Incapacitants under the Chemical Weapons Convention, University of Bradford, UK; Dando, M. and Furmanski, M. 2006, 'Midspectrum incapacitant programs', in M. Wheelis, L. Rózsa and M. Dando (eds), Deadly Cultures: Biological Weapons Since 1945, Harvard University Press, Cambridge, Mass.; Davison, op. cit.; Furmanski, M. 2007, 'Historical military interest in low-lethality biochemical agents', in Pearson et al., op. cit.; Pearson, A. 2006, 'Incapacitating biochemical weapons: science, technology, and policy for the 21st century', Nonproliferation Review, vol. 13, no. 2.

17 Crowley, op. cit., p. 82; Guo Ji-Wei and Xue-sen Yang 2005, 'Ultramicro, nonlethal and reversible: looking ahead to military biotechnology', Military Review, July-August, as cited in Pearson, A. 2007, 'Late and postCold War research and development of incapacitating biochemical weapons', in Pearson et al., op. cit.

18 Hess, L., Schreiberová, J., Málek, J. and Fusek, J. 2007, 'Drug-induced loss of aggressiveness in the macaque rhesus', Proceedings of 4th European Symposium on Non-Lethal Weapons, 21st-23rd May 2007, Ettlingen, Germany, European Working Group on Non-Lethal Weapons, Pfinztal: Fraunhofer ICT, V15; Hess, L., Schreiberova, J. and Fusek, J. 2005, 'Pharmacological non-lethal weapons', Proceedings of the 3rd European Symposium on Non-Lethal Weapons, 10th-12th May 2005, Ettlingen, Germany, European Working Group on Non-Lethal Weapons, Pfinztal: Fraunhofer ICT, V23; Davison, N. and Lewer, N. 2006, Bradford Non-Lethal Weapons Research Project (BNLWRP)—Research Report No. 8, University of Bradford, UK, p. 50.

19 Klochikin, V., Pirumov, V., Putilov, A. and Selivanov, V. 2003, 'The complex forecast of perspectives of NLW for European application', Proceedings of the 2nd European Symposium on Non-Lethal Weapons, 13th-14th May 2003, Ettlingen, Germany, European Working Group on Non-Lethal Weapons, Pfinztal: Fraunhofer ICT; Klochinkhin, V., Lushnikov, A., Zagaynov, V., Putilov, A., Selivanov, V. and Zatekvakhin, M. 2005, ‘Principles of modelling of the scenario of calmative application in a building with deterred hostages', Proceedings of the 3rd European Symposium on Non-Lethal Weapons, 10th-12th May 2005, Ettlingen, Germany, European Working Group on Non-Lethal Weapons, Pfinztal: Fraunhofer ICT.

20 Crowley, op. cit., pp. 76-8; Davison, op. cit., pp. 105-42; Furmanski, op. cit.; Pearson, 2007, op. cit.; Furmanski and Dando, op. cit.

21 Organisation for the Prevention of Chemical Weapons (OPCW), Executive Council 2013, Statement by Ambassador Robert P. Mikulak, United States Delegation to the OPCW at the Seventy Second Session of the Executive Council, Seventy-Second Session EC-72/NAT.8, 6-7 May 2013, 6 May 2013. In his statement, ambassador Mikulak declared '[i]n this context, I also wish very clearly and directly to reconfirm that the United States is not developing, producing, stockpiling, or using incapacitating chemical agents'.

22 International Committee of the Red Cross (ICRC) 2010, Expert Meeting: Incapacitating Chemical Agents, Implications for International Law, Montreux, Switzerland, 24-26 March, p. 3. 


\title{
Box 18.1 Contemporary Czech Republic research into incapacitating chemical agents
}

\begin{abstract}
The Czech Republic has had a longstanding research program into incapacitants dating from

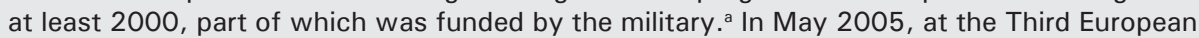
Symposium on Non-Lethal Weapons, Czech researchers delivered a paper ${ }^{\mathrm{b}}$ describing their investigations over several years, administering rhesus monkeys with various pharmacological cocktails in order to determine which combinations and doses resulted in 'fully reversible immobilization'. The paper also described how '[f]ully reversible analgesic sedation was ... tested in man', utilising the triple combination of dexmedetomidine, midazolam and fentanyl given to patients undergoing surgery, and a second combination of dexmedetomidine, midazolam and ketamine, which was tested on 10 nurses. ${ }^{c}$

In a 2007 follow-up paper, Czech researchers described how they 'decided to test new combinations [of drugs] for suppression or complete abolition of aggressive behaviour' in macaque monkeys. ${ }^{d}$ The researchers claim that 'the results can be used to pacify aggressive people during medical treatment (mental disease), terrorist attacks and during production of new pharmacological nonlethal weapons'. ${ }^{\text {In }}$ July 2010, Czech researchers published a paper describing their studies inducing immobilisation in orang-utans and chimpanzees utilising a naphthylmedetomidine-ketamine-hyaluronidase combination. ${ }^{\dagger}$ Although the results of this research were presented in terms of facilitating the relocation and painless medical examination of the animals, such research may also potentially be applicable to incapacitant development. Czech researchers have also investigated a number of alternative means of agent delivery including via inhalation administration, which was initially tested on rats and then on human 'volunteers', ${ }^{g}$ who were reported to have been children in hospital. ${ }^{\text {h }}$ Researchers have also explored conjunctival, nasal, transbucal, sublingual and transdermal administration. ${ }^{i}$
\end{abstract}

${ }^{a}$ According to Davison and Lewer, research to develop sedative and anaesthetic agent combinations for use as weapons had been funded by the Czech Army under Project No: MO 03021100007 . See Davison and Lewer, op. cit., p. 50.

${ }^{\mathrm{b}}$ Hess et al., 2005, op. cit.

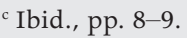

${ }^{\text {d }}$ Hess et al., 2007,op. cit., p. 6.

e Ibid., p. 7.

${ }^{\mathrm{f}}$ Hess, L., Votava, M., Schreiberová, J., Málek, J. and Horáček, M. 2010, 'Experience with a naphthylmedetomidine-ketamine-hyaluronidase combination in inducing immobilization in anthropoid apes', Journal of Medical Primatology, vol. 39, no. 3 (June), pp. 151-9.

${ }^{g}$ Hess et al., 2005, op. cit., pp. 11-12.

${ }^{\text {h }}$ Davison, op. cit., p. 128.

${ }^{\mathrm{i}}$ Hess et al., 2005, op. cit., pp. 10-14.

\section{Potential dangers and proposed utility}

Proponents of incapacitants have promoted their development and use in certain law-enforcement scenarios (such as hostage-taking situations) where there is a need to rapidly and completely incapacitate a single or a group of individuals without causing death or permanent disability. Incapacitants have also been raised as a possible tool in a variety of military operations, especially in situations where combatants and noncombatants are mixed. ${ }^{23}$

23 See, for example: Fenton, G. 2007, 'Current and prospective military and law enforcement use of chemical agents for incapacitation', in Pearson et al., op. cit., pp. 103-23; Whitbred, G. 2006, 'Offensive use of chemical 
A broad range of observers, however-including scientific and medical professionals, arms-control organisations, international legal experts, human rights monitors and humanitarian organisations, as well as a number of states - is highly sceptical about the development and utility of incapacitants, highlighting the fact that such weapons are not inherently nonlethal, even if they were to be used with a nonlethal intent. In their 2003 study conducted under the auspices of the Federation of American Scientists, Klotz et al. developed a predictive model illustrating 'why seemingly non-lethal incapacitating agents may be quite lethal in actual use'. ${ }^{24}$ In their conclusion, they stated: 'We have shown, at least within the approximations of our simple (but generous) two receptor equilibrium model, that even with a therapeutic index of 1,000 (above any known anaesthetic or sedative agent), a chemical agent used as an incapacitating weapon can be expected to cause about $10 \%$ fatalities. ${ }^{25}$

Furthermore, as Pearson has noted, even such predictive modelling will potentially underestimate fatalities when an incapacitant is used in real-life situations where there is uncontrollable variability 'both in terms of exposure (uneven concentration and exposure time) and within the target population (age, size, gender, health status and individual susceptibility) ${ }^{\prime}{ }^{26}$ As a result of such considerations, the British Medical Association believes:

The agent whereby people could be incapacitated without risk of death in a tactical situation does not exist and is unlikely to in the foreseeable future. In such a situation, it is and will continue to be almost impossible to deliver the right agent to the right people in the right dose without exposing the wrong people, or delivering the wrong dose. ${ }^{27}$

Similarly, Klotz et al. concluded that 'genuinely non-lethal chemical weapons are beyond the reach of current science' ${ }^{28}$

technologies by US special operations forces in the global war on terrorism', Maxwell Paper, no. 37, Air University Press, Maxwell Air Force Base, Ala. It should be noted that other authors have questioned the utility of incapacitants in certain proposed scenarios such as premeditated hostage situations, due to the availability of countermeasures. See Wheelis, M. 2007, 'Non-consensual manipulation of human physiology using biochemicals', in Pearson et al., op. cit., p. 6.

24 Klotz, L., Furmanski, M. and Wheelis, M. 2003, 'Beware the siren's song: why "non-lethal" incapacitating chemical agents are lethal', Federation of American Scientists Paper, <http://www.fas.org/bwc/papers/sirens_ song.pdf $>$ (viewed 8 February 2012).

25 Ibid., p. 7.

26 Pearson, 2007, op. cit., p. 70.

27 British Medical Association (BMA) 2007, The Use of Drugs As Weapons: The Concerns and Responsibilities of Healthcare Professionals, BMA, London, p. 1.

28 Klotz et al., op. cit., p. 1. 


\section{Box 18.2 Use of Chemical Incapacitant by the Russian Federation}

Concerns about incapacitants were heightened following the use of a presumed derivative of fentanyl by Russian security forces to free more than 800 hostages held by heavily armed Chechen separatists in the Dubrovka Theatre in Moscow, in October 2002. ${ }^{\text {a }}$ According to reports, 30 minutes after an incapacitant was pumped into the theatre, the building was stormed by Russian Spetsnaz special forces who killed all of the Chechen hostage takers, including those left unconscious from the incapacitant, in apparent contravention of international humanitarian law. ${ }^{b}$ Although the hostages were released, more than 120 died as a result of the direct effects of the agent used or of airway constriction due to their incapacitation. An undetermined, but large, additional number of hostages suffered long-term damage, or died prematurely in the years after the siege. ${ }^{c}$

Treatment of the hostages who had been poisoned was delayed and compromised by the refusal of the Russian authorities to state publicly what type of incapacitant had been used in the theatre for four days after the siege had ended. ${ }^{d}$ On 30 October 2002, the Russian health minister, Yuri Shevchenko, identified the incapacitating agent as 'a mixture of derivative substances of the fast action opiate Fentanyl'. ${ }^{e}$ Shevchenko further stated that 'I officially declare: chemical substances which might have fallen under the jurisdiction of the international convention on banning chemical weapons were not used during the special operation'. ${ }^{\dagger}$ The minister refused, however, to be more precise about the chemicals used even on 11 December 2002 when faced with a parliamentary question. He said it was a 'state secret'. ${ }^{g}$ In 2012, results of trace analysis undertaken in the United Kingdom of extracts of clothing and urine from survivors indicated that the aerosol comprised a mixture of two anaesthetics, carfentanil and remifentanil. ${ }^{h}$ At the time of writing, the Russian authorities have still not publicly stated exactly what chemical or chemicals were used.

a For descriptions of the incident, see, for example: Koplow, op. cit.; Pearson et al., op. cit.; British Broadcasting Corporation (BBC) 2004, Horizon: The Moscow Theatre Siege, BBC 2, 15 January, <http:// www.bbc.co.uk/science/horizon/2004/moscowtheatretrans.shtml> (viewed 30 July 2009); Amnesty International 2003, Rough Justice: The Law and Human Rights in the Russian Federation, October, Amnesty International, London, AI Index EUR 46/054/2003.

${ }^{\mathrm{b}}$ Specifically, the prohibition against attacking those recognised as hors de combat. See: Henckaerts, J. 2005, 'Study on customary international humanitarian law: a contribution to the understanding and respect for the rule of law in armed conflict', International Review of the Red Cross, vol. 87, no. 857, p. 203.

' Wheelis, M. 2010, 'Human impact of incapacitating chemical agents', inICRC, op. cit.; Levin, D. and Selivanov, V. 2009, 'Medical and biological issues of NLW development and application', Proceedings of the 5th European Symposium on Non-Lethal Weapons, 11th-13th May 2009, Ettlingen, Germany, European Working Group on Non-Lethal Weapons, Pfinztal: Fraunhofer ICT, V23, p. 7.

d See, for example: Human Rights Watch 2002, 'Independent commission of inquiry must investigate raid on Moscow theater: inadequate protection for consequences of gas violates obligation to protect life', Press release, 30 October 2002, Human Rights Watch.

e 'Russian experts discuss use of fentanyl in hostage crisis', ITAR-TASS, [from Moscow in English], 2112 hrs GMT, 30 October 2002, FBIS-SOV-2002-1030, as cited by Perry Robinson, October 2007, op. cit.

${ }^{f}$ Alison, S. 2002, 'Russian confirms siege gas based on opiate fentanyl', [from Moscow for Reuters], 1257 hrs ET, 30 October 2002, as cited in Perry Robinson, 2007, op. cit.

g Amnesty International, op. cit., p. 53.

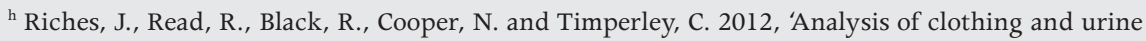
from Moscow theatre siege casualties reveals carfentanil and remifentanil use', Journal of Analytical Toxicology, vol. 36, pp. 647-56. 
In addition, Nixdorff and Melling have surveyed the potential long-term physiological consequences of exposure to incapacitants. Although insufficient research has been undertaken to produce conclusive results, they believe that:

Numerous human and animal studies have shown that exposure to incapacitating biochemical agents may induce heterogeneous cognitive and physiological impairments and [may] lead to long term health effects. This is even more pronounced when exposures to incapacitating agents are combined with other factors such as stress or activation of the immune system. ${ }^{29}$

Even if all technical barriers to the development of a truly 'nonlethal' incapacitant were overcome, there are a number of serious risks and damaging consequences that could follow from the development of such weapons. These include the following.

- Creeping legitimisation: Perry Robinson believes that attempts by certain states, particularly the United States, to legitimise the development and use of incapacitants threaten to erode the norm against the weaponisation of toxicity. ${ }^{30}$ He believes that this 'creeping legitimisation' presents the greatest danger to the existing prohibitions on chemical and biological weapons and to the re-emergence of chemical and biological warfare. ${ }^{31}$

- Proliferation and legitimisation by states: Pearson has warned that efforts to develop incapacitating weapons 'may well gather steam as more nations become intrigued by them and, observing the efforts of Russia and the United States, become convinced not only that effective and acceptably "non-lethal" incapacitating agents can be found, but that their use will be legitimized'. ${ }^{32}$

- Proliferation to, and misuse by, non-state actors: Analysts have highlighted the potential utility of incapacitants to a range of non-state actors including criminals, terrorists, paramilitary organisations and armed factions in failing or failed states many of whom would not feel as constrained as states by international law and concerns about lethality. ${ }^{33}$

- Use as a lethal force multiplier: There are concerns that incapacitants will be used by both military and law-enforcement agencies, not as an alternative

29 Nixdorff, K. and Melling, J. 2007, 'Potential long-term physiological consequences of exposure to incapacitating biochemicals', in Pearson et al., op. cit., p. 165.

30 Perry Robinson, J. 2007, 'Categories of challenge now facing the Chemical Weapons Convention', 52nd Pugwash CBW Workshop: 10 Years of the OPCW: Taking Stock and Looking Forward, Noordwijk, the Netherlands, 17-18 March, p. 20; Perry Robinson, J. October 2007, Non-lethal Warfare and the Chemical Weapons Convention, Further Harvard Sussex Program submission to the OPCW Open-Ended Working Group on Preparations for the Second CWC Review Conference, Harvard Sussex Program.

31 Perry Robinson, 2007, op. cit., p. 19.

32 Pearson, 2006, op. cit., p. 172.

33 See, for example: ibid., p. 169; Wheelis, M. and Dando, M. 2005, ‘Neurobiology: a case study of the imminent militarization of biology', International Review of the Red Cross, vol. 87, no. 859, p. 564. 
to lethal force, but as a means to make lethal force more deadly. During the October 2002 Moscow theatre siege, those Chechen hostage takers who were rendered unconscious by the incapacitant were then reportedly shot where they lay by Russian forces rather than being arrested. ${ }^{34}$

- Facilitation of torture and other human rights violations: As well as potentially being utilised for torture and ill treatment of individuals, incapacitants could also facilitate repression of groups by, for example, allowing the capture, en masse, of large numbers of people participating in peaceful demonstrations.

- Militarisation of biology: Analysts ${ }^{35}$ have warned that the continuing utilisation of the life sciences in the development of incapacitants could potentially open the way to more malign objectives, such as the widespread repression of entire populations.

- Camouflage for lethal chemical weapons programs: States could exploit the limited transparency mechanisms required under the Chemical Weapons Convention (CWC), for incapacitants and other toxic chemicals designated for use in law enforcement, to hide illicit activities. ${ }^{36}$

- Confusion between lethal and 'nonlethal' chemical weapons: A state using a 'nonlethal' incapacitant during an armed conflict may be perceived by another party as having used a lethal chemical weapon and thus initiate an escalating cycle of retaliation leading to actual use of lethal chemical agents. ${ }^{37}$

\section{Advances in science and technology}

In the light of the previous research that has been conducted by certain states into incapacitants, the potential application of the current advances in the life sciences, particularly genomics, biotechnology, synthetic biology and neuroscience, ${ }^{38}$ to incapacitating weapons development is a cause for concern. Trapp has highlighted the potential implications of the misuse of such research:

The explosion of knowledge in neuroscience, bioregulators, receptor research, systems biology and related disciplines is likely to lead to the discovery, amongst others, of new physiologically-active compounds that can selectively interfere with certain regulatory functions in the brain or other organs, and presumably even modulate human behavior

\footnotetext{
34 Koplow, D. 2006, 'The Russians and the Chechens in Moscow in 2002', in Non-Lethal Weapons: The Law and Policy of Revolutionary Technologies for the Military and Law Enforcement, Cambridge University Press, Cambridge, pp. 100-13.

35 BMA, op. cit., p. 1; Perry Robinson, October 2007, op. cit., p. 32; Wheelis and Dando, op. cit., pp. 553-71.

36 Perry Robinson, 2007, op. cit., p. 31.

37 Pearson, 2006, op. cit., p. 170.

38 See, for example: The Royal Society 2011, Brain Waves, Module 1: Neuroscience, Society and Policy, Science Policy Centre, The Royal Society, London; The Royal Society, 2012, op. cit.; Andreasen, op. cit.; Society of Neuroscience, op. cit.
} 
in a predictable manner. Some of these new compounds (or selective delivery methods) may well have a profile that could make them attractive as novel candidate chemical warfare agents. ${ }^{39}$

Wheelis and Dando had previously surveyed developments and future trends in neurobiology and concluded that there were indications that military interest was already directed towards the next generation of substances affecting the brain and central nervous system:

In addition to drugs causing calming or unconsciousness, compounds on the horizon with potential as military agents include noradrenaline antagonists such as propranolol to cause selective memory loss, cholecystokinin $\mathrm{B}$ agonists to cause panic attacks, and substance $\mathrm{P}$ agonists to induce depression. The question thus is not so much when these capabilities will arise-because arise they certainly will-but what purposes will those with such capabilities pursue. ${ }^{40}$

Indeed in 2005, Boken, a toxicologist with the Croatian Ministry of Defence, published a paper warning of the potential use of a range of bio-regulators in warfare and terrorist activities:

Recent years have seen a rapid advance in the discovery of new bioregulators, especially of the incapacitating ones, in the understanding of their mode of action and synthetic routes for manufacture. Some of these compounds may be many hundreds of times more potent than the traditional chemical warfare agents. Some very important characteristics of new bioregulators that would offer significant military advantages are novel sites of toxic action; rapid and specific effects; penetration of protective filters and equipment, and militarily effective physical incapacitation. $^{41}$

Advances in discovery or synthetic production of potential incapacitating agents have occurred in parallel with developments in particle engineering and nanotechnology that could allow the delivery of biologically active chemicals to specific target organs or receptors. The implications of this were highlighted in the 2008 report by the National Research Council on Emerging Cognitive Neuroscience and Related Technologies, ${ }^{42}$ which warned that nanotechnologies could be used to overcome the blood-brain barrier and thereby 'enable

39 Trapp, R. 2010, “Incapacitating chemical agents": some thoughts on possible strategies and recommendations', in ICRC, op. cit., p. 65.

40 Wheelis and Dando, op. cit., p. 10.

41 Boken, S. 2005, 'The toxicology of bioregulators as potential agents of bioterrorism', Arh Hig Tokiskol, vol. 56, pp. 205-11.

42 National Research Council 2008, Emerging Cognitive Neuroscience and Related Technologies, The National Academies Press, Washington, DC. 
unparalleled access to the brain. Nanotechnologies can also exploit existing transport mechanisms to transmit substances into the brain in analogy with the Trojan horse. ${ }^{\prime 3}$ The report also highlighted the potential threats resulting from developments in nanotechnologies or gas-phase techniques that allow dispersal of highly potent chemicals over wide areas. It noted that at present 'pharmacological agents are not used as weapons of mass effect, because their large-scale deployment is impractical' as it is 'currently impossible to get an effective dose to a combatant'. The report states, however, that 'technologies that could be available in the next 20 years would allow dispersal of agents in delivery vehicles that would be analogous to a pharmacological cluster bomb or a land mine'. ${ }^{44}$ Despite the interest in the development of incapacitants by certain states, and the ongoing advances in relevant science and technology with dual-use application, the international governmental and scientific communities currently seem unwilling or unable to establish and implement effective regulatory controls in this area.

The following sections of this chapter seek to apply a holistic arms-control approach to this issue in order to explore potential routes for effective regulation of such agents.

\section{Applying a holistic arms-control approach to the regulation of incapacitants}

For many years the governmental and non-governmental arms-control communities have sought to develop strategies to combat the proliferation of chemical and biological weapons to state and non-state actors. Recognising that reliance upon a single disarmament or arms-control agreement alone would not guarantee success, scholars have explored a number of concepts seeking to broaden the range of possible regulatory mechanisms. Utilising and building upon such work, particularly the concepts of preventative arms control $^{45}$ and webs of prevention (or protection), ${ }^{46}$ the author has sought to develop a 'holistic arms control' (HAC) framework for regulation. Although the proposed HAC analytical framework concentrates upon existing arms-control

\footnotetext{
43 Ibid., p. 135.

44 Ibid., p. 137.

45 See, for example: Altmann, J. 2006, 'Preventive arms control: concept and design', in J. Altmann, Military Nanotechnology: Potential Applications and Preventive Arms Control, Routledge, London.

46 See, for example: Pearson, G. 1998, 'The vital importance of the web of prevention', in Proceedings of the Sixth International Symposium on Protection against Chemical and Biological Warfare Agents, Stockholm, 11-15 May; Pearson, G. 2001, 'Why biological weapons present the greatest danger', Seventh International Symposium on Protection against Chemical and Biological Warfare Agents, Stockholm; McLeish, C. and Rappert, B. (eds) 2007, A Web of Prevention: Biological Weapons, Life Sciences, and the Governance of Research, Earthscan, London.
} 
and disarmament measures, ${ }^{47}$ it attempts to widen the range of applicable mechanisms for regulation, and also the nature of the actors involved in such regulatory measures.

Consequently, HAC can be thought of as a framework for analysis to aid the development of a comprehensive, layered and flexible approach to arms control that

- is developed for and unique to the specific type of weapon or technology under consideration rather than for a broad grouping of weapons

- is potentially applicable to all stages of a weapon's existence (that is, research, development, mass production, stockpiling, deployment, use, transfer and destruction)

- is responsive to developments in science and technology (and will be able to regulate weapons that have not yet been invented)

- seeks to identify the types of permissible and non-permissible weapons, acknowledges where ambiguity lies, and seeks to develop mechanisms for resolving such ambiguities

- seeks to clearly identify existing constraints upon the permitted use of weapons - that is, legitimate targets (for example, whether this would include armed combatants, terrorist organisations, criminals, civilians), legitimate types of operations (for example, whether this would include law enforcement, military operations other than war, armed conflict) and how such operations should be conducted (rules of engagement); acknowledges where existing ambiguity lies and highlights potential mechanisms for resolving such ambiguities

- is responsive to developments in the nature of the use/misuse of weapons in practice

- is not necessarily limited to a single existing arms-control or disarmament treaty, but actively explores and seeks to incorporate states' existing responsibilities under the full range of relevant international law and applicable agreements

- is responsive to developments in international law, particularly those limiting types and use of weapons

- incorporates measures to facilitate effective national implementation as well as verification, enforcement and transparency mechanisms

47 This chapter does not, therefore, explore a range of parallel processes that can potentially play important roles in preventing or ameliorating the effects of incapacitant weapons attack, including broadband defence measures, strengthening public health surveillance and response, and so on. For further discussion of these issues, see, for example, Pearson, 1998, op. cit.; Pearson, 2001, op. cit.; McLeish and Rappert, op. cit. 
- recognises that states are the prime actors in existing regulatory regimes, and allows for and encourages participation by the full range of relevant stakeholders.

Applying this approach to the case of incapacitants, a HAC regime can be envisioned comprising

- state-led activities

- adherence to comprehensive legal prohibitions against chemical and biological weapons (CBW) enshrined in the Geneva Protocol, the Biological and Toxin Weapons Convention (BTWC) and the Chemical Weapons Convention (CWC)

- adherence to international humanitarian law (notably, the four Geneva conventions and two additional protocols) and international human rights law (including the Convention against Torture, the International Covenant on Civil and Political Rights and the Universal Declaration on Human Rights)

- adherence to other relevant international law and agreements including the Rome Statute of the International Criminal Court, the Single Convention on Narcotic Drugs and the UN Convention on Psychotropic Substances

- effective monitoring, verification, investigation and enforcement of the above obligations

- application of stringent export controls and interdiction measures.

- engagement by civil society

- conducting societal monitoring and verification

- developing a 'culture of responsibility' amongst the scientific and medical communities built upon strong normative and ethical standards

- developing and advocating mechanisms to strengthen the regime.

Whilst certain authors have previously examined the application of a range of state-led mechanisms for the regulation of incapacitants, ${ }^{48}$ the importance of the life-science community's engagement in this issue has been underexplored. In the following sections, the author will, therefore, briefly examine the potential application of the two most pertinent arms-control regimes - the Chemical Weapons Convention and the Biological and Toxin Weapons Conventionbefore concentrating upon the potential roles that civil society, and particularly

48 See, for example: Crowley, op. cit.; Casey-Maslen, S. 2010, Non-Kinetic-Energy Weapons Termed 'NonLethal': A Preliminary Assessment under International Humanitarian Law and International Human Rights Law, Geneva Academy of International Humanitarian Law and Human Rights, Geneva; ICRC, op. cit.; International Committee of the Red Cross (ICRC) 2012, Toxic Chemicals As Weapons for Law Enforcement: A Threat to Life and International Law? Synthesis paper, September, International Committee of the Red Cross, Geneva; International Committee of the Red Cross (ICRC) 2013, 'Incapacitating Chemical Agents': Law Enforcement, Human Rights Law and Policy Perspectives, Expert Meeting, Montreux, Switzerland, 24-26 April 2012, ICRC, Geneva, 13 January 2013. 
the scientific and medical communities, can play in preventing the misuse of biomedical research for hostile purposes, most notably, the development of incapacitating weapons.

\section{Biological and Toxin Weapons Convention}

Article I of the BTWC declares that:

Each State Party to the Convention undertakes never in any circumstances to develop, produce, stockpile or otherwise acquire or retain:

1. Microbial or other biological agents, or toxins, whatever their origin or method of production, of types and in quantities that have no justification for prophylactic, protective or other peaceful purposes.

2. Weapons, equipment or means of delivery designed to use such agents or toxins for hostile purposes or in armed conflict. ${ }^{49}$

Article I, together with the extended understandings agreed at successive BTWC review conferences, ${ }^{50}$ makes it clear that the convention is comprehensive in its scope and that all naturally or artificially created or altered microbial and other biological agents and toxins, as well as their components, regardless of their origin and method of production are covered. Because some possible candidate incapacitants, such as bio-regulators including neurotransmitters, could be considered biological agents or toxins, a range of such incapacitants would be covered by the BTWC.

Although the BTWC does appear to cover certain incapacitants, there are ambiguities regarding the nature and scope of such coverage. For example, although the use of incapacitants of a biological origin in armed conflict or for 'hostile purposes' would be banned, the delineation between prohibited 'hostile purposes' and permitted 'peaceful purposes' has not been fully established under the convention. Consequently, it is unclear how the use of incapacitants of biological origin for 'military operations other than war' (MOOTW), would

49 Convention on the Prohibition of the Development, Production and Stockpiling of Bacteriological (Biological) and Toxin Weapons and their Destruction, 1972, 1015 UNTS 163, art. 1.

50 See, for example, Seventh BWC Review Conference Final Document (2012): '1. ... Conference declares that the Convention is comprehensive in its scope and that all naturally or artificially created or altered microbial and other biological agents and toxins, as well as their components, regardless of their origin and method of production and whether they affect humans, animals or plants, of types and in quantities that have no justification for prophylactic, protective or other peaceful purposes, are unequivocally covered by Article I. 2. The Conference reaffirms that Article I applies to all scientific and technological developments in the life sciences and in other fields of science relevant to the Convention ... 3. The Conference reaffirms that the use by the States Parties, in any way and under any circumstances, of microbial or other biological agents or toxins, that is not consistent with prophylactic, protective or other peaceful purposes, is effectively a violation of Article I.' United Nations 2012, Final Document of the Seventh Review Conference, Geneva, 5-22 December 2011, BWC/CONF.VII/7, 13 January 2012, art. I, paras 1-3. 
be regulated by the BTWC. To date, there have been no determinations of these issues by the BTWC states parties. ${ }^{51}$ Further important limitations on the value of the BTWC (and its control regime) as a tool to regulate incapacitants arise from its current lack of effective verification and compliance mechanisms, and also the absence of an international organisation that could coordinate such activities and facilitate implementation by states parties. ${ }^{52}$

\section{Chemical Weapons Convention}

Although certain states in their background scientific papers to the seventh BTWC Review Conference highlighted the potential dangers of the misuse of biologically active agents such as bio-regulators and peptides that could be used as incapacitants, currently discussions on the regulation of such weapons have largely concentrated on the Chemical Weapons Convention (CWC). The CWC prohibits the development, production, stockpiling, transfer and use of chemical weapons. ${ }^{53}$ In addition, it requires that all existing stocks of chemical weapons ${ }^{54}$ and chemical weapons production facilities be destroyed..$^{55}$ The treaty is of unlimited duration and is designed to be far more comprehensive in scope and application than any prior international agreement on chemical weapons. It is overseen by its own treaty body, the Organisation for the Prevention of Chemical Weapons (OPCW), including a technical secretariat of more than 500 inspectors, scientists, legal experts and ancillary staff headed by the director-general, which carries out the daily work of monitoring, verifying and facilitating implementation of the convention.

Although the convention prohibits chemical weapons, it allows for the controlled peaceful use of toxic chemicals. Article II.2 of the convention defines a 'toxic chemical' as 'any chemical, regardless of its origin or method of production, which, through chemical action on life processes, can cause death, temporary

\footnotetext{
51 Analysis was undertaken of all relevant documents pertaining to this issue publicly available up to 10 September 2013.

52 Although there is no equivalent of an OPCW for the BTWC, the Sixth BTWC Review Conference decided to create and fund a (three-person) Implementation Support Unit (ISU) within the UN Office for Disarmament Affairs (UNODA) of the UN Office at Geneva. The ISU was launched in August 2007 and its mandate was renewed and extended by the Seventh BTWC Review Conference to run until 2016. The ISU provides administrative support to, and prepares documentation for, meetings agreed by the BTWC Review Conference. The ISU also facilitates communication among states parties, international organisations, and scientific and academic institutions, as well as NGOs. It also acts as a focal point for submission of information by and to states parties, and will support, as appropriate, the implementation by the states parties of the decisions and recommendations of the Sixth and Seventh BTWC Review Conferences. The ISU, however, has no authority to undertake verification or compliance activities.

53 Convention on the Prohibition of the Development, Production, Stockpiling and Use of Chemical Weapons and on their Destruction (Chemical Weapons Convention), 1993, art. I.1.

54 Ibid., art. I.3.

55 Ibid., art. I.4.
} 
incapacitation or permanent harm to humans or animals'.$^{56}$ The convention therefore covers a wide range of chemicals within its scope of regulation including certain chemical agents that could be used as incapacitants.

To determine whether the use of a toxic chemical such as an incapacitant would be in conformity with the CWC, the intention or purpose for its use needs to be determined. Under Article II.1 of the convention, chemical weapons are defined as 'toxic chemicals or their precursors, except where intended for purposes not prohibited by the Convention, as long as the types and quantities are consistent with such purposes'. ${ }^{57}$

Such 'purposes not prohibited' are defined under Article II.9 and include:

(c) Military purposes not connected with the use of chemical weapons and not dependent on the use of the toxic properties of chemicals as a method of warfare;

- Law enforcement including domestic riot control purposes. ${ }^{58}$

It is therefore clear that the use of toxic chemicals such as incapacitants for purposes not provided for in Article II.9 (for example, as a method of warfare) would be prohibited, as would development, production, acquisition, stockpiling, retention or transfer of these chemicals for such purposes (under Article I of the CWC).

There are, however, a number of ambiguities in the CWC and limitations in its current implementation that could seriously restrict its ability to effectively regulate incapacitants. Although the use of toxic chemicals is permitted for law enforcement 'as long as the types and quantities are consistent with such purposes', ${ }^{59}$ there is no definition of 'law enforcement' in the convention. Furthermore, no OPCW policymaking organ has made any interpretative statements elaborating the scope or nature of permitted law-enforcement activities or regarding which toxic chemicals (if any) - save riot-control agents - could be used for such purposes. Consequently, the extent to which incapacitants could be used (if at all) for activities such as counterterrorist operations is contested. ${ }^{60}$ Unfortunately, and despite attempts made by a number of CWC states parties to raise this issue at the 2013 Third Review Conference, ${ }^{61}$ there

\footnotetext{
56 Ibid., art. II.2.

57 Ibid., art. II.1.

58 Ibid., art. II.9.

59 Ibid., art. II.1.

60 For divergent argumentation on this issue, see: Fidler, D. 2007, 'Incapacitating chemical and biochemical weapons and law enforcement under the Chemical Weapons Convention', in Pearson et al., op. cit.; von Wagner, A. 2007, 'Toxic chemicals for law enforcement including domestic riot control purposes under the Chemical Weapons Convention', in Pearson et al., op. cit.

61 See, in particular, the statements by Germany, Switzerland, the United Kingdom and the United States made on 8 and 9 April 2013 in the General Debate of the Third Special Session of the Conference of the States Parties to Review the Operation of the Chemical Weapons Convention (Third Review Conference), The Hague, 8-19 April 2013, all available from the OPCW web site: <www.opcw.org >.
} 
has been a collective failure by the CWC states parties and policymaking organs to effectively address the regulation of incapacitants under the convention. It is therefore left to individual states parties to interpret the scope and nature of their obligations with regard to the regulation of such agents.

\title{
Box 18.3 The ICRC and Incapacitants: A call to action
}

\begin{abstract}
A range of civil society organisations and researchers has urged the international governmental community-particularly the OPCW and the CWC states parties - to take action to address the dangers of the potential proliferation and inappropriate use of incapacitants. ${ }^{\text {a }}$ The ICRC, however, has noted that '[a]lthough there have been exhortations by some States and by some in academic circles to address these issues, there has been little or no movement to date in the relevant multilateral fora'. ${ }^{b}$ Consequently in March 2010, the ICRC convened the first of two expert meetings to explore the implications of these issues for international law. The meeting brought together a group of 33 government and independent experts who were joined by ICRC staff members. ${ }^{\circ}$ For details of the second ICRC meeting, see: ICRC, 2013, op. cit. In the subsequent report of the meeting, the ICRC urged '[s]tates to give greater attention to the implications for international law of "incapacitant chemical agents"'. The organisation also noted that '[t]here is currently an opportunity to address preventatively the challenges and risks identified'd (emphasis added). In addition, the report concluded that "[t]here is a clear need to tackle the issues raised by "incapacitating chemical agents" in appropriate fora engaging a broad range of experts including policy makers, law-enforcement professionals, security personnel, military personnel, health professionals, scientists and lawyers with IHL [international humanitarian law], human rights and disarmament expertise'e (emphases added).
\end{abstract}

a See, for example: Crowley, op. cit., esp. pp. 57-101, 117-19; Pearson et al., 2007, op. cit.; Perry Robinson, 2007 and October 2007, op. cit.

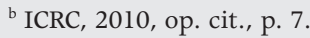

c Ibid., p. 3.

${ }^{\text {d }}$ ICRC, 2010, op. cit., p. 75.

e Ibid., p. 75.

\section{Engagement by the medical and scientific communities}

Given the evident ambiguities and limitations of the existing state-centric chemical and biological weapons control regimes, compounded by their inadequate implementation by certain states parties, a great responsibility lies upon the life-science community as a whole and individual researchers in particular to ensure that their activities do not contribute to the development of a new generation of chemical and biological weapons, including incapacitants. Furthermore, it can be argued that there is an obligation upon life scientists to move beyond such 'personal regulation' and to take a far more proactive role in monitoring and regulating incapacitating agent research and combating the potential misuse of such agents. This section will explore potential avenues for greater engagement and action through the application of societal verification as 
a complement to the existing official verification mechanisms, the development of a culture of responsibility amongst the scientific and medical communities, and finally explore the possible roles that scientists, academics and other civilsociety actors can play in informing and influencing the actions of states in this area.

\section{Societal monitoring and verification}

Although there is no agreed formal definition of societal monitoring and verification, Diseroth describes societal verification as

connot[ing] the involvement of civil society in monitoring national compliance with, and overall implementation of, international treaties or agreements. One important element is citizens' reporting of violations or attempted violations of agreements by their own government or others in their own country ... A more recent development is civil society monitoring of global compliance with international agreements. In contrast to official verification organisations employing professional experts, societal verification may involve the whole of society or groups within it. ${ }^{62}$

The establishment of a global societal monitoring and verification networkinvolving large numbers of civil society actors resident in all states party to relevant chemical or biological treaties who are able to monitor their state's implementation of treaty obligations - appears to be unlikely in the near to medium terms. As Rotblat acknowledges, '[e]ven if governments were persuaded to pass laws to make reporting legitimate', which itself would be a revolutionary development and counter to existing practice in arms control and disarmament policy and the practice of many states, 'this goes so much against traditional loyalties that it would require a considerable educational effort to induce people to act on it voluntary' ${ }^{63}$ Consequently, he believes that implementation of societal verification 'requires a change in certain attitudes of the general public, which may take time'. ${ }^{64}$

A more limited form of societal verification, however, can be envisaged, comprising a smaller number of activist researchers who have access to the relevant technical expertise and can, at the very least, undertake open-source monitoring and analysis, and potentially conduct field missions. Due to resource, personnel, political and security constraints, such groups are likely to be limited

62 Deiseroth, D. 2000, 'Societal verification: wave of the future?' in VERTIC, 2000 Verification Yearbook, p. 265.

63 Rotblat, J. 1993, 'Societal verification', in J. Rotblat, J. Steinberger and B. Udgaonkar, A Nuclear-WeaponFree World: Desirable? Feasible? Westview Press, Boulder, Colo., p. 108.

64 Ibid., p. 105. 
in terms of the countries from which they can operate and consequently the quantity and quality of information they are able to receive, particularly from inaccessible regions and closed or semi-closed authoritarian countries.

\section{Open-source monitoring and analysis}

A small number of academic and non-governmental organisations ${ }^{65}$ have undertaken monitoring of open-source data, often utilising a range of national oversight and transparency mechanisms, to obtain information relating to the research, development and utilisation of incapacitants. ${ }^{66}$ Such open-source monitoring and analysis are time-consuming, resource intensive and the information obtained is often limited as a result of national security restrictions, commercial confidentiality considerations and limited access to research published in certain countries. In addition, there is much inaccurate or biased reporting disseminated by both proponents and opponents of such weapons.

Despite the methodological difficulties and the limitations in the information obtained, such work is vital to the formation of an informed public discourse on the existing threats and potential dangers of the proliferation and misuse of these weapons. In addition it can also help in the development of timely and realistic publicly available threat assessments relating to $\mathrm{R} \& \mathrm{D}$, deployment or utilisation of such weapons in specific countries. Furthermore, information derived from civil society research can be sent to relevant intergovernmental organisations, most notably the OPCW.

\section{Field missions and witness testimony}

Independent scientists, health professionals and non-governmental organisations (NGOs) can sometimes collect their own information, first hand, from onsite investigations or may be able to utilise information (for example, witness testimony) and analyse materials (for example, weapons shells, clothing fragments, soil samples) obtained from other civil society actors operating in the field (for example, journalists, national NGOs). There are several potential constraints upon such investigations including access, logistics and translation; safety considerations for researchers and witnesses; and difficulties ensuring chain of custody, as well as establishing the representativeness of the information

65 See, for example, the publications of: Biological Weapons Prevention Programme, Bradford Non-Lethal Weapons Research Project; Centre for Arms Control and Non-Proliferation; Federation of American Scientists; Harvard Sussex Project; International Network of Engineers and Scientists for Global Responsibility; Pugwash Conferences on Science and World Affairs; and the Sunshine Project.

66 For discussion, see: Crowley, M. 2010, 'Monitoring and opposing the misuse of incapacitants - exploring the potential roles for independent scientists', in J. Finney and V. Slaus (eds), Assessing the Threat of Weapons of Mass Destruction, Nato Science for Peace and Security Series E, Human and Societal Dynamics-Volume 61, IOS Press, Amsterdam, pp. 114-32. 
obtained. Despite such constraints, material collected during field missions can provide information that could not be obtained by any other means - for example, allowing identification of toxic chemical agents utilised during a military or law-enforcement operation.

\section{Box 18.4 Independent Analysis of a New Riot-Control Agent Used in the West Bank}

In July 2005, the Israeli Army reportedly employed a new riot-control agent against Palestinian and Israeli civilian protesters that resulted in severe skin injuries. The Israeli Army refused to identify the agent; however, scientists based in the United Kingdom obtained one of the munitions utilised, and following physical and chemical analyses, were able to identify the contents as capsaicin with an inert carrier and a dispersal agent. ${ }^{a}$ The results were found to correspond with the commercially available 'Pepperball Tactical Powder'. The paper noted that '[s]kin injuries of the severity described had not previously been reported with this agent, and would be difficult to manage for clinicians who were unaware of the nature of the agent'. ${ }^{b}$ As well as alerting clinicians to the nature and effects of chemical agents they may face in the future, such research can also help to identify possible international transfers of chemical agents and devices.

${ }^{a}$ Hay, A., Giacaman, R., Sansur, R. and Rose, S. 2006, 'Skin injuries caused by new riot control agent used against civilians on the West Bank', Medicine, Conflict and Survival, vol. 22, no. 4 (OctoberDecember).

${ }^{\mathrm{b}}$ Ibid.

\section{Building a culture of responsibility within the life- science and biomedical communities}

In its 2004 public statement 'Preventing hostile use of the life sciences', the ICRC declared: 'If measures to prevent the hostile use of advances in the life sciences are to work, a culture of responsibility is necessary among individual life scientists. This applies whether these scientists are working in industry, academia, health, defense or in related fields such as engineering and information technology. ${ }^{\prime 67}$

According to the ICRC, such a culture of responsibility is also needed 'within the institutions that employ scientists and fund research in the life sciences' ${ }^{68}$ Similar calls to the scientific and medical communities have also been made by the states parties to the BTWC and the CWC at review conferences. ${ }^{69}$

67 International Committee of the Red Cross (ICRC) 2004, Preventing Hostile Use of the Life Sciences: From Ethics and Law to Best Practice, 11 November 2004, International Committee of the Red Cross, Geneva, $<$ http://projects.exeter.ac.uk/codesofconduct/ Chronology/Principles_Actionpoints_11Nov04.pdf > (viewed 14 January 2012).

68 Ibid.

69 For example, see: Third Review Conference of the Parties to the Convention on the Prohibition of the Development, Production and Stockpiling of Bacteriological (Biological) and Toxin Weapons and on their Destruction, Final Document, Part II, BWC/CONF.III/23, 9-2 September 1991, p. 3; Report of the Second Special Session of the Conference of the States Parties to Review the Operation of the Chemical Weapons Convention (Second Review Conference), 7-18 April 2008, RC-2/4, 18 April 2008. 
The remaining sections of this chapter will explore the current range of initiatives being undertaken by those in the scientific and medical communities to nurture a culture of responsibility, beginning with the growing recognition of the dual-use dilemma and the consequent requirement for effective oversight of research. This will then be followed by a discussion of the potential utility of oaths, codes and pledges and the parallel processes of education and awarenessraising in building the appropriate norms of behaviour for the scientific and biomedical communities. The practical application of such principles by individual scientists through such practices as whistleblowing will be explored as well as the duty of individual scientists to inform the policies and practices of governments in this area.

\section{Research oversight and the 'dual-use dilemma'}

To date, much of the discourse amongst the life-science community concerning how best to combat the proliferation and misuse of chemical and biological weapons has concentrated on tackling the dual-use dilemma and has been framed in terms of regulating the actions of individual life scientists conducting 'academic' research projects and publishing 'academic' articles. Highly influential in this discourse have been the 2003 Fink Report (Biotechnology Research in An Age of Terrorism) ${ }^{70}$ and the 2006 Lemon Report (Globalisation, Biosecurity and the Future of the Life Sciences), both produced under the auspices of the National Research Council of the US National Academies. Both reports highlighted the importance of taking a comprehensive approach to analysing 'dual-use' research of potential concern. The Lemon Report recommended the adoption of 'a broadened awareness of threats beyond the classical "select agents" and other pathogenic organisms and toxins, so as to include, for example, approaches for disrupting host homeostatic and defense systems and for creating synthetic organisms'.71 The broad threat spectrums enunciated by both reports, particularly that of the Lemon Committee, appear to capture incapacitants within their scope.

As a result of the concerns and recommendations outlined in the Fink and Lemon reports and the work of others, ${ }^{72}$ a range of oversight structures and processes

\footnotetext{
70 National Research Council 2004, Biotechnology Research in an Age of Terrorism, [Fink Report], The National Academies Press, Washington, DC, p. 114.

71 National Research Council 2006, Globalisation, Biosecurity and the Future of the Life Sciences, [Lemon Report], The National Academies Press, Washington, DC, p. 216.

72 A range of analysts has subsequently highlighted the need to address further potential actors of concern beyond individual life-science researchers. Garfinkel et al., for example, defined three major points for potential policy intervention - namely: 'commercial firms that sell synthetic DNA (oligonucleotides, genes or genomes) to users; owners of laboratory "bench-top" DNA synthesizers, with which users can produce their own DNA; the users (consumers) of synthetic DNA themselves and the institutions that support and oversee their work.' See: Garfinkel, M., Endy, D., Epstein, G. and Friedman, R. 2007, Synthetic Genomics: Options for Governance, J. Craig Venter Institute, Rockville, Md, and San Diego, Calif.
} 
was established by governments, scientific bodies, academic institutions, funders and publishers to review potential dual-use research, assessing the risks and benefits of such research to determine whether they need to be modified or withdrawn. ${ }^{73}$

Analysing the application of oversight measures in practice, however, Rappert believes that 'such procedures rarely conclude that manuscripts, grant applications or experiment proposals should not be undertaken or restricted'. In 2009, van Aken and Hunger analysed the application of biosecurity policies agreed by a group of 32 influential science journals under which manuscripts could be modified or rejected where 'the potential harm of publication outweighs the potential societal benefits' ${ }^{74}$ Despite such policies having been established in 2003, van Aken and Hunger found that no manuscript has ever been rejected on security grounds. ${ }^{75}$ Rappert believes the 'same could be said' of those funders who have established submission-oversight systems. ${ }^{76}$ Furthermore, Rappert believes that 'even more notable with these review processes is the infrequency with which they have identified items "of concern" in the first place' ${ }^{77}$ Whilst information relating to the research controls of government departments (especially defence-related ones) is not readily available, Rappert believes that in relation to universities and other publicly funded agencies, 'it seems justifiable to conclude that - barring dramatic changes - oversight processes will identify little research as posing security concerns and will stop next to nothing' ${ }^{\prime}{ }^{78}$

Others have criticised the voluntary nature of the existing controls on lifescience dual-use research. For example, commenting upon the release of a draft of the National Science Advisory Board for Biosecurity (NSABB) 'Proposed Framework for the Oversight of Dual Use Life Sciences Research: Strategies for Minimizing the Potential Misuse of Research Information ${ }^{\prime}{ }^{79}$ the Sunshine Project director, Hammond, stated that the 'NSABB is divorced from reality if its members believe that another set of voluntary NIH [National Institutes of Health] guidelines is sufficient, and would be remotely effective, at preventing

\footnotetext{
73 For a discussion of such initiatives, see: Rappert, B. 2008, 'The benefits, risks, and threats of biotechnology', Science \& Public Policy, vol. 35, no. 1, pp. 37-44.

74 Journal Editors and Authors Group 2003, 'Uncensored exchange of scientific results', Proceedings of the National Academy of Sciences, vol. 100, no. 4, p. 1464.

75 van Aken, J. and Hunger, I. 2009, 'Biosecurity policies at international life-science journals', Biosecurity and Bioterrorism, vol. 7, no. 1, pp. 61-72.

76 Rappert, B. 2010, 'Introduction: education as...', in B. Rappert (ed.), Education and Ethics in the Life Sciences: Strengthening the Prohibition of Biological Weapons, ANU E Press, Canberra, pp. 8-9. Rappert cites the UK Biotechnology and Biological Sciences Research Council, the UK Medical Research Council, the Wellcome Trust, the Centers for Disease Control, and the Southeast Center of Regional Excellence for Emerging Infectious Diseases and Biodefence.

77 Ibid., p. 9.

78 Ibid., p. 9

79 National Science Advisory Board for Biosecurity (NSABB) 2007, Proposed Framework for the Oversight of Dual Use Life Sciences Research: Strategies for Minimizing the Potential Misuse of Research Information, National Science Advisory Board for Biosecurity, Bethesda, Md.
} 
dual-use disasters' ${ }^{80}$ Research conducted by the Sunshine Project from 2004 to 2007 indicated that many US organisations obliged to follow NIH guidelines did not do so. ${ }^{81}$ A 2007 Sunshine Project survey discovered that 18 of the top20 US biotechnology companies did not comply with existing voluntary NIH biotechnology guidelines. ${ }^{82}$ Instead of a voluntary approach, Hammond stated that '[e]ffective federal management of dual-use risks requires making safety and security oversight truly mandatory and subject to the sobering light of public scrutiny'. ${ }^{83}$

As well as concerns about the implementation of such voluntary oversight systems in practice, a further concern relates to the limited range of issues being considered by such bodies. The discourse and much of the current activity appear to be concentrated upon preventing the diffusion of dual-use knowledge, skills and materials to various non-state actors with malign intent - principally, terrorist organisations. Insufficient attention has been given to utilising existing dual-use monitoring mechanisms or adopting additional processes to specifically combat the misuse of dual-use expertise in state programs, even though national CBW research and development programs arguably pose a greater danger to the CWC and BTWC than non-state actors.

\section{Oaths, codes and pledges for the life-science community}

One approach to building a culture of responsibility has been through the development of a range of non-binding ethical codes, codes of conduct and oaths or pledges. An early advocate of such activities was Joseph Rotblat, who declared in his 1995 Nobel acceptance speech that:

The time has come to formulate guidelines for the ethical conduct of scientists, perhaps in the form of a voluntary Hippocratic Oath ... At a time when science plays such a powerful role in the life of society, when the destiny of the whole of mankind may hinge on the results of scientific research, it is incumbent on all scientists to be fully conscious of that role, and conduct themselves accordingly. I appeal to my fellow scientists to remember their responsibility to humanity. ${ }^{84}$

The development of ethical codes of conduct became one of the priority areas during the BTWC inter-sessional process. Subsequently, initiatives supporting

\footnotetext{
80 Sunshine Project 2007, 'Earth calling NSABB: voluntary compliance won't work', Press release, 17 April 2007.

81 See, for example: Sunshine Project 2004, Mandate for Failure: The State of IBCs in an Age of Bioweapons Research, <http://www.sunshine-project.org/biodefense/ibcreport.html> (viewed 11 January 2012).

82 Supporting correspondence available at <http://www.sunshine-project.org/publications/pr/support/ deregistries.pdf $>$ (viewed 11 January 2011).

83 Sunshine Project, 2007, op. cit.

84 Rotblat, J. 1995, Remember Your Humanity, Nobel Lecture, Oslo, 10 December 1995, <http://nobelprize. org/nobel_prizes/peace/laureates/1995/rotblat-lecture.html> (viewed 11 January 2012).
} 
such codes have been undertaken by a wide range of scientific associations and organisations including the American Society of Microbiology ${ }^{85}$ the National Academy of Sciences, The Royal Society, ${ }^{86}$ the International Centre for Genetic Engineering and Biotechnology, the International Union of Biochemistry and Molecular Biology and the International Council for the Life Sciences. These activities have been complemented and stimulated by the ICRC as well as the work of individual scientists ${ }^{87}$ and academics. ${ }^{88}$

Such codes may well help to sensitise life scientists to the dangers of dual-use research, and reinforce the importance of, and promulgate, ethical 'red lines' where the legal prohibitions or normative taboos are already clearly defined and widely accepted. The effectiveness of such an approach, to date, has, however, been questioned by a range of scholars including Corneliussen, Dando, Perry Robinson and Rappert. ${ }^{89}$ One important limitation of the majority of such initiatives is that the resulting codes are aspirational and non-binding in nature with no clearly identified penalties elaborated for those individuals who breach the prohibitions, or mechanisms established to monitor and enforce such prohibitions.

Recognising the limitations of self-governance initiatives to effect change in this area, some have called for codes of conduct to become binding, with those breaching such codes facing sanction from their peers (or the state). For example, Rotblat, in a letter to a Pugwash Workshop on Science, Ethics and Society in 2004, stated his belief that:

[S]ome believe that the search for knowledge overrides all other considerations and that scientists should be entitled to ignore the ethical elements of their work ... The harm to society that has resulted from such attitudes has brought science into disrepute, and action is needed to restore the proper image of science. The introduction of a 'hippocratic' oath is our example of such action, but it should perhaps be given more than a symbolic value. Perhaps the time has come for a

85 American Society of Microbiology (ASM) 2005, Code of Ethics (Revised and approved by ASM Council in 2005), American Society of Microbiology, Washington, DC.

86 The Royal Society 2005, The Roles of Codes of Conduct in Preventing the Misuse of Scientific Research, The Royal Society, London.

87 See Atlas, R. and Somerville, M. 2007, 'Life sciences or death science: tipping the balance towards life with ethics, codes and laws', in McLeish and Rappert, op. cit.

88 See, for example, Revil, J. and Dando, M. 2006, 'A Hippocratic oath for life scientists', EMBO Reports, vol. 7.

89 Rappert, B. 2010, Biological Weapons and Codes of Conduct, <http://projects.exeter.ac.uk/codesofconduct/ Chronology/index.htm> (viewed 22 December 2011). 
binding code of conduct, where only those who abide by the code should be entitled to be practicing scientists, something which applies now to medical practice [emphasis added]. ${ }^{90}$

Examination of the literature, however, reveals that no such binding codes of conduct prohibiting research, development or utilisation of incapacitating agents have been established by any national or international scientific organisation to date.

Furthermore, Rappert has noted that 'if codes are to go beyond reiterating platitudes about the abhorrence of using modern biology toward malign ends, then they are likely to confront major issues of controversy. For instance, codes could comment on the acceptability of disputed attempts to develop "non-lethal" incapacitating agents. ${ }^{91}$ Areas of dispute or controversy, such as incapacitants, are the ones, however, where such codes remain silent or at best provide ambiguous guidance. Similarly, as with dual-use research oversight, whilst numerous codes condemn and seek to prevent the involvement of scientists in the development of biological and chemical weapons by non-state actors, it is questionable whether enough energy has been devoted to targeting the involvement of life scientists in state-run weapons programs.

Corneliussen has asked

why voluntary self-governance regimes - and codes of conduct in particular - are being given so much attention in policy discussions about preventing the misuse of biological research when they appear to have significant shortcomings in practice. Indeed, why have individual scientists become the target of the policy discussions when it is generally accepted within the disarmament community that the greatest risk of misuse is at the level of national biological weapons programmes ... Preventing these state-level programmes in the future should therefore be a primary concern, rather than implementing codes of conduct for life scientists. ${ }^{92}$

Corneliussen further contends that:

[T] he current sole focus on codes, and the extensive investment of resources that accompanies it, might well serve to detract from other more

\footnotetext{
90 Rotblat, J. 2004, 'Letter to workshop', in Report of 2nd Pugwash Workshop: Science, Ethics and Society, Ajaccio, Corsica, 10-12 September 2004, <http://www.pugwash.org/reports/ees/corsica2004/corsica2004. htm\#attach2> (viewed 22 December 2011).

91 Rappert, B. 2005, 'Biological weapons and the life sciences: the potential for professional codes', Disarmament Forum. Volume 1: Science Technology and the CBW Regimes, p. 56.

92 Corneliussen, F. 2006, 'Adequate regulation, a stop-gap measure, or part of a package? Debates on codes of conduct for scientists could be diverting attention away from more serious questions', EMBO Reports, vol. 7 (Special Issue), p. 53.
} 
crucial regulatory measures that target not only individual scientists but also state programmes. Without this plurality of regulatory measures in place, codes of conduct are doomed to fail. ${ }^{93}$

More recently there have been some indications of an increasing awareness amongst certain life-science communities of the dangers of cooption into state programs and initiatives undertaken to address these dangers (see Box 18.5).

\section{Box 18.5 A Pledge for Neuroscientists}

In January 2010, Dr Curtis Bell, senior scientist emeritus at the Oregon Health and Science University, circulated a pledge intended to foster opposition amongst neuroscientists to the application of neuroscience to 'torture and other forms of coercive interrogation or manipulation that violate human rights and personhood'. a According to Bell, 'such applications could include drugs that cause excessive pain, anxiety, or trust, and manipulations such as brain stimulation or inactivation'. ${ }^{b}$ Furthermore, signatories would oppose the application of neuroscience to 'aggressive war ... illegal under international law'. The pledge states that a 'government which engages in aggressive wars should not be provided with tools to engage more effectively in such wars. Neuroscience can and does provide such tools. Examples include ... drugs which damage the effectiveness of soldiers on the other side. ${ }^{\prime c}$

Under the pledge, neuroscientists commit to making themselves aware of the potential misuse of neuroscience for violations of 'basic human rights or international law such as torture and aggressive war' and commit to refusing to 'knowingly participate in the application of Neuroscience to violations of basic human rights or international law'.d Bell acknowledges that '[s]igning this pledge will not stop aggressive wars or human rights violations, or even the use of neuroscience for these purposes'; however, he believes that 'by signing, neuroscientists will help make such applications less acceptable'.e

${ }^{a}$ Bell, C. 2010a, Pledge by Neuroscientists to Refuse to Participate in the Application of Neuroscience to Violations of Basic Human Rights or International Law, <http://spreadsheets.google.com/viewform?f ormkey $=\mathrm{dEF} 4 \mathrm{RFhhSWZwNktCakYtbTdkdlcxckE6MA}>$ (viewed 4 December 2011); Bell, C. 2010b, 'Letter to International Society for Neuroethology', <http://neuroethology.org/cgi-bin/dada/mail. cgi/archive/emaillist/20100106211821/> (viewed 4 December 2011); Bell, C. n.d., 'Responsibilities of neuroscientists concerning aggressive war and torture', Poster display, <http://files.me.com/ curtiscbell/pu0ycj> (viewed 4 December 2011).

${ }^{\mathrm{b}}$ Bell, 2010a, op. cit.

${ }^{\mathrm{c}}$ Ibid.

${ }^{\mathrm{d}}$ Ibid.

e Bell, C. 2010c, 'Neurons for peace: take the pledge, brain scientists', New Scientist, no. 2746 (8 February).

Despite the energy and resources expended upon the development and promotion of codes, however, Rappert's stark conclusion is that 'efforts to devise meaningful codes have largely floundered'. Rappert believes that '[i]n no small part, this has been due to the lack of prior awareness and attention by researchers as well as science organisations to the destructive applications of the life sciences. Before codes can help teach, education is needed.' ${ }^{\prime 4}$

93 Ibid., p. 54.

94 Rappert, 2010, op. cit., p. 14. 


\section{Education and awareness-raising}

In 2005, following a series of interactive seminar discussions held with life scientists at 15 UK universities, Dando and Rappert concluded there was little evidence that participants 'regarded bioterrorism or bioweapons as a substantial threat ... considered that developments in the life sciences research contributed to biothreats ... were aware of the current debates and concerns about dual-use research; or ... were familiar with the BWC' ${ }^{95}$ In 2006, Rappert et al. presented a report to the Sixth BTWC Review Conference, which stated that 'despite the recent international attention given to the problem of the potential misuse of the life sciences', the initial UK findings were essentially replicated in later seminars in the United Kingdom and in Finland, Germany, the Netherlands, South Africa and the United States. ${ }^{96}$ Subsequent experience by Dando and Rappert 'of carrying out seminars in 16 different countries with a few thousand life scientists in over 110 different departments has consolidated these findings' ${ }^{97}$

In a 2009 Nature article, Dando highlighted the 'lack of engagement with this issue among life scientists', which he considered 'alarming', ${ }^{98}$ specifically with regard to the consequent dangers of the misuse of scientific and technological advances for the development of incapacitant weapons. Dando and colleagues have identified the current lack of adequate biosecurity teaching as an important factor contributing to such low levels of awareness amongst life scientists. Following their review of the effectiveness of existing education and awarenessraising initiatives, Rappert et al. conclude:

In such circumstances it is quite unrealistic to expect that simply, for example, adding a lecture to a standard course in the life sciences will make a great deal of difference ... in depth implementation of the BWC within States Parties requires a significant effort on education and outreach for such implementation to be effective. To achieve this, a simple declaration as at previous Review Conferences about the

95 Dando, M. and Rappert, B. 2005, Codes of Conduct for the Life Sciences: Some Insights from UK Academia, Bradford Briefing Paper No. 16 (2nd series), University of Bradford, UK, p. 23.

96 Rappert, B., Chevrier, M. and Dando, M. 2006, In-Depth Implementation of the BTWC: Education and Outreach, Report presented at Sixth BTWC Review Conference, University of Bradford, UK, para. 89.

97 Whitby, S. and Dando, M. 2010, 'Biosecurity awareness-raising and education for life scientists: what should be done now?' in B. Rappert (ed.), Education and Ethics in the Life Sciences: Strengthening the Prohibition of Biological Weapons, ANU E Press, Canberra. For a detailed discussion, see: Rappert, B. 2007, Biotechnology, Security and the Search for Limits: An Inquiry into Research and Methods, Palgrave, Basingstoke, UK; Rappert, B. 2009, Experimental Secrets: International Security, Codes, and the Future of Research, University Press of America, Lanham, Md.

98 Dando, M. 2009, 'Biologists napping while work militarized', Nature, vol. 460, no. 7258, p. 951. Dando's concerns are echoed in an accompanying Nature editorial entitled: 'A question of control: scientists must address the ethics of using neuroactive compounds to quash domestic crises.' 
importance of education will be insufficient and States Parties will need to take concerted action to ensure increased educational provision and outreach. ${ }^{99}$

Similarly, Whitby and Dando believe that 'correcting this deficiency in educationand awareness-levels of life scientists will be a massive task' ${ }^{100}$ It is one that will require action by a broad range of constituencies involved in life-science education including, governments, bodies responsible for the administration of standards in higher education, funders of life-science education, civil society groups and NGOs involved in the production of educational material, and teachers and trainers. ${ }^{101}$

Whilst a number of albeit relatively small and isolated initiatives are now being undertaken to educate and raise awareness amongst life scientists regarding dual-use dilemmas and the potential dangers of research being misused for chemical or biological weapons development, ${ }^{102}$ there do not appear to be any sustained activities designed to foster greater awareness and knowledge of such issues beyond the life-science community. Rappert has noted that '[s]cant efforts made prior to 2001 (and even since) by scientists to popularise how their work might aid the production of bioweapons indicate the historical pattern of not seeking to foster wider debate and awareness' ${ }^{\prime}{ }^{103}$

It is, however, worth considering whether and how those scientists, academics and educators concerned about incapacitants and who are currently conducting CBW education and awareness-raising activities can also engage with key civil society actors in areas such as human rights, humanitarian law and medical ethics who at present have limited or no knowledge of the dangers posed by the potential harnessing of advances in chemistry and the life sciences to hostile purposes. The education and engagement of such expert communities would enrich and inform the existing discourse concerning incapacitants and broaden the range of actors seeking effective restrictions of such weapons. In considering such issues it may be worth exploring the roles of civil society awareness-raising initiatives and public education in helping to build successful multidisciplinary coalitions dedicated to addressing complex issues such as the prohibition of antipersonnel landmines and cluster munitions, addressing climate change, and promoting the establishment of the International Criminal Court.

\footnotetext{
99 Rappert et al., 2006, op. cit., paras 89, 90.

100 Whitby and Dando, op. cit., p. 182.

101 For further discussion, see: Dando, M. 2009, 'Dual-use education for life scientists', Disarmament Forum, vol. 1, pp. 41-4

102 Project on Building a Sustainable Capacity in Dual-Use Bioethics, available from Bradford University web site, <http://www.brad.ac.uk/bioethics/About/> (viewed 4 December 2011).

103 Rappert, 2010, op. cit., p. 16.
} 


\section{Developing and applying ethical standards for health professionals}

In addition to life scientists, the participation of physicians and other health professionals in previous state-run incapacitant weaponisation programs has been documented in a range of countries including the United Kingdom, the United States and South Africa. ${ }^{104}$ More recently, a number of health professionals in certain countries have voiced support for medical involvement in the research and development of incapacitant weapons. Anaesthesiologists who were engaged in the Czech Republic's incapacitant weapons development program have highlighted counterterrorism considerations: 'many agents used in everyday practice in anaesthesiology can be employed as pharmacological non-lethal weapons. An anaesthetist familiar with the pharmacokinetics and pharmacodynamics of these agents is thus familiar with this use. As a result, he or she can play a role in combating terrorism.' ${ }^{105}$

The necessity of medical participation for the viability of incapacitant research has been highlighted by Gross, who believes that chemical incapacitants are among a limited range of 'nonlethal' weapons that are in effect "'medicalized" in that they rely on advances in neuroscience, physiology, and pharmacology and on the active participation of physicians and other medical workers' ${ }^{106}$

In comparison with the life-science community, amongst certain sectors, at least, of the medical professional community, ethical discourse regarding the involvement in development and use of 'nonlethal' chemical weapons appears to be more advanced. There are a number of ethical codes and declarations that are potentially applicable and may well constrain the involvement of health professionals in this area. First, there is a range of declarations and regulations adopted by the World Medical Association(WMA) that guide health professionals in situations of conflict and unrest ${ }^{107}$ and specifically prohibit their involvement

104 See, for example: Maclean, A. 2006, Historical Survey of the Porton Down Volunteer Programme, Ministry of Defence, London, <http://www.mod.uk/NR/rdonlyres/7211B28A-F5CB-4803-AAAC-2D34F3DBD961/0/ part_iv.pdf $>$ (viewed 17 August 2011), pp. 109-42; Ketchum, J. 2006, Chemical Warfare: Secrets Almost Forgotten, James S. Ketchum (self-published); Gould, C. and Folb, P. 2002, Project Coast: Apartheid's Chemical and Biological Warfare Programme, United Nations Institute for Disarmament Research, Geneva.

105 Hess et al., 2005, op. cit.

106 Gross, M. 2010, 'Medicalized weapons and modern war', Hastings Center Report, vol. 40, no. 1, pp. 34-5.

107 World Medical Association (WMA) 1956, Regulations in Times of Armed Conflict, Adopted by the 10th World Medical Assembly, Havana, Cuba, October 1956, last amended by the 35th World Medical Assembly, Tokyo, Japan, 2004, and editorially revised at the 173rd Council Session, Divonne-les-Bains, France, May 2006, para. 2 . 
in torture, ill treatment and other forms of human rights abuse. ${ }^{108}$ The WMA has also sought to develop ethical guidelines prohibiting medical involvement in the development of chemical or biological weapons. ${ }^{109}$

In addition, guidance has also been developed by certain national medical associations and other medical bodies ${ }^{110}$ on the ethical considerations surrounding health professionals' involvement in specific weapons research or weapons development more generally. A number of such bodies have also established a range of mechanisms and structures to implement ethical standards including ethics boards that have the authority to suspend or disbar physicians from practising medicine in cases of extreme misconduct.

There are thus ethical frameworks and mechanisms in place that describe and regulate the duty of health professionals to abide by and promote aspects of human rights and international humanitarian law, and specifically prohibit engagement in acts such as torture or the development of biological and toxin weapons. Whilst these and other ethical standards - particularly those concerned with medical research involving human subjects ${ }^{11}$ — can in theory be applied to the development and utilisation of incapacitants, this does not appear to have occurred in a consistent manner to date. There are no widely accepted guidelines specifically determining the permissibility or non-permissibility of physician involvement in the development, testing or utilisation of so-called 'nonlethal' weapons in general and incapacitants in particular. Indeed the issue appears, at present, to be both underexplored and contentious, with a spectrum of opinions held by health professionals and medical ethicists.

Amongst national medical associations, it is the British Medical Association (BMA) that has taken the lead in the development of ethical guidance for the health community on the issue of 'nonlethal' chemical weapons, and in

108 World Medical Association (WMA) 1975, Declaration of Tokyo, Adopted by the 29th World Medical Assembly, Tokyo, Japan, October 1975, and editorially revised at the 170th Council Session, Divonne-lesBains, France, May 2005, and the 173rd Council Session, Divonne-les-Bains, France, May 2006.

109 World Medical Association (WMA) 1990, Declaration on Chemical and Biological Weapons, Adopted by the 42nd World Medical Assembly, Rancho Mirage, Calif., October 1990, and rescinded at the WMA General Assembly, Santiago, 2005; World Medical Association (WMA) n.d., Washington Declaration on Biological Weapons, paras 18 and 19.

110 For example, the US Army textbook of military ethics urges medical professionals 'to stay in the business of healing and not hurting, which includes not participating in or contributing to weapons research and development'. Frisina, M. E. 2003, 'Medical ethics in military biomedical research', in T. E. Beam and L. R. Sparacino (eds), Military Medical Ethics, vol. 2, Office of the Surgeon General/Borden Institute, Washington, DC, pp. 533-61, as cited in Gross, op. cit., p. 37.

111 See, for example: World Medical Association (WMA) 1964, Declaration of Helsinki, Adopted by the 18th WMA General Assembly, Helsinki, , June 1964, and last amended at the 59th WMA General Assembly, Seoul, October 2008, <http://www.wma.net/en/30publications/10policies/b3/index.html> (viewed 22 July 2011); Nuremberg Code, 1949, as detailed in Trials of War Criminals before the Nuremberg Military Tribunals under Control Council Law, vol. 2, no. 10, pp. 181-2, US Government Printing Office, Washington, DC, 1949 , available from: Office of Human Subjects Research, US National Institutes of Health, <http://ohsr.od.nih.gov/ guidelines/nuremberg.html> (viewed 22 July 2011). 
particular incapacitants. In its 2007 publication Drugs As Weapons, which explored the implications of incapacitant research, development and use, ${ }^{112}$ the BMA declared that:

[D]octors should not knowingly use their skills and knowledge for weapons' development for the same reasons that these ethical considerations oppose doctors' involvement in torture and the development of more effective methods of execution. In other words, the duty to avoid doing harm rises above, for instance, a duty to contribute to national security. ${ }^{113}$

The report specifically recommends that national organisations that represent healthcare professionals should

[w] ork to promote the norms prohibiting the use of poisons, and therefore the BWC and the CWC. They should further promote understanding that the use of drugs as weapons would violate such norms ... Advocate against the use of drugs as weapons and not be involved in the training of military or law enforcement personnel in the administration of drugs as weapons. ${ }^{114}$

Despite the activities of the BMA, the issue does not appear to have been specifically addressed formally by the WMA during its general assembly or in any other public WMA policy body. ${ }^{115}$ Given the importance of medical participation to research, development, testing and utilisation of incapacitant weapons, the development of clear guidance in this area is needed.

\section{Harvard Sussex draft convention}

The Harvard Sussex Project (HSP) has proposed an alternative approach to addressing individual responsibility and culpability in the development or misuse of chemical and biological weapons, through the development of criminal sanctions. Meselson and Robinson have argued that '[a]ny development, production, acquisition, or use of biological and chemical weapons is the result of decisions and actions of individual persons, whether they are government officials, commercial suppliers, weapons experts, or terrorists'. They contend, however, that the BTWC and CWC 'are directed primarily to the actions of states, and address the matter of individual responsibility to only a limited degree' ${ }^{116}$

\footnotetext{
112 BMA, op. cit.

113 Ibid., p. 20.

114 Ibid., p. 24.

115 A review was undertaken of all relevant publicly available World Medical Association documentation from January 1990 to December 2011.

116 Meselson, M. and Perry Robinson, J. 2004, 'A draft convention to prohibit biological and chemical weapons under international criminal law', Fletcher Forum of World Affairs, vol. 28, no. 1 (Winter), p. 57.
} 
In order to address this failing, HSP has developed a Draft Convention to Prohibit Biological and Chemical Weapons under International Criminal Law. If enacted, the HSP draft convention would make it a crime under international law for any person knowingly: to develop, produce, acquire, retain, transfer or use biological or chemical weapons; to order, direct or knowingly render substantial assistance to those activities; or to threaten to use biological or chemical weapons. ${ }^{117}$

Under the HSP draft convention, each state party would be required to 'establish jurisdiction with respect to such crimes according to established principles of judicial law', and where the state has jurisdiction and is satisfied that the facts warrant such action, 'to submit those cases to competent authorities for the purpose of extradition or prosecution'. Furthermore, with respect to the actual use of CBWs, each state party would be required to 'establish jurisdiction over all persons found on its territory regardless of their nationality or place of the offence'. ${ }^{118}$

The HSP draft convention is a civil society initiative that will require considerable state support for it to be adopted by the international governmental community. One potential route previously explored by the HSP is 'for a group of states to submit the proposed convention or a similar draft in the form of a resolution for consideration by the UN General Assembly [UNGA], seeking its referral to the UNGA Sixth (legal) Committee for negotiation of an agreed text ${ }^{\prime}{ }^{119}$ Robinson has stated that '[o]nce we are satisfied that the political environment is favourable, our plan is to convene an international conference that will bring together policy makers, jurists and exponents of the Draft Convention'. ${ }^{120}$

\section{Nonparticipation/whistleblowing}

Any serious attempt by state or non-state actors to develop new or indeed existing chemical or biological weapons, be they considered 'nonlethal' or otherwise, would require the involvement of an array of scientists, engineers, technicians and other ancillary workers. Whilst such staff are essential to the development, production, stockpiling, transfer and use of such weapons, they are also potentially capable of 'blowing the whistle' on such research and development programs through public denunciations, leaking information to

117 For the full text of the present draft of the convention, see $<$ http://www.sussex.ac.uk/Units/spru/hsp/ Harvard-Sussex-Program-draft-convention-Text.html> (viewed 4 June 2010). Also see accompanying Draft Legal Commentary, <http://www.sussex.ac.uk/Units/spru/hsp/Draft \%20Convention \%20supporting \%20 docs/HSP\%20papers/Legal\%20Commentary.pdf> (viewed 4 June 2010).

118 Preamble to HSP Convention, <http://www.sussex.ac.uk/Units/spru/hsp/Harvard-Sussex-Programdraft-convention-Text.html $>$ (accessed 4 June 2010).

119 Perry Robinson, J. 2011, 'Criminalization of biological and chemical armament', CBW Conventions Bulletin, (Special Issue), February 2011, p. 4.

120 Ibid., p. 5. 
journalists or by reporting concerns about potential or realised breaches of national regulations or violations of international treaties directly to the relevant national or international regulatory bodies.

In his Nobel acceptance speech, Rotblat stated that:

The purpose of some government or industrial research is sometimes concealed, and misleading information is presented to the public. It should be the duty of scientists to expose such malfeasance. 'Whistleblowing' should become part of the scientist's ethos. This may bring reprisals; a price to be paid for one's convictions. The price may be very heavy. ${ }^{121}$

Deiseroth highlights the particular vulnerability of whistleblowers:

Compared with normal citizens, employees are in a special situation because they owe their employer a certain loyalty and, by law, are normally not allowed to disclose internal or confidential information. Whistle-blowers, therefore, need protection if they make a disclosure in good faith and on the basis of reliable evidence. ${ }^{122}$

Similarly, Falter notes that 'it is neither realistic nor legitimate to put the full burden of whistle-blowing and potential retaliation on individual scientists and their moral sensibilities' ${ }^{123}$ Indeed, whilst it is the duty of individual scientists to make known their concerns about the misuse of scientific research for activities that breach ethical standards or international law, it is the responsibility of the scientific community as a whole to ensure that such whistleblowers are fully protected. This was recognised by the ICRC in their 2004 statement, which declared that '[t]hose working in life sciences who voice concern and take responsible action require and deserve political and professional support and protection', and the corresponding action point, which was to 'ensure that adequate mechanisms exist for voicing such concerns without fear of retribution'. ${ }^{124}$

Although a number of states such as South Africa, ${ }^{125}$ the United Kingdom ${ }^{126}$ and the United States ${ }^{127}$ have legislation relating to whistleblowing activities

\footnotetext{
121 Rotblat, 1995, op. cit.

122 Deiseroth, op. cit., p. 266.

123 Falter, A. 2010, 'Including civil society into confidence building: protecting whistleblowers and societal verification', in Finney and Slaus, op. cit., p. 289.

124 ICRC, 2004, op. cit.

125 Government of South Africa 2000, Protected Disclosures Act, <http://www.workinfo.com/free/Sub_for_ legres/data/Disclosure/protected.htm $>$ (viewed 23 January 2012).

126 Government of the United Kingdom 1998, Public Interest Disclosure Act, available on the UK National Archives web site: <http://www.legislation.gov.uk/ukpga/1998/23/contents> (viewed 23 January 2012).

127 Government of the United States of America 1989, US Federal Whistleblower Protection Act, 5 USC, s. 1201.
} 
on their statute books, the effectiveness of such legislation and its enforcement are variable. ${ }^{128}$ Furthermore, Martin, who has long experience of working with, and seeking to protect, whistleblowers in many different spheres, believes that 'the track record of whistle-blower protection measures - whistle-blower laws, hot-lines, ombudsmen and the like - is abysmal. In many cases, these formal processes give only an illusion of protection. Codes of ethics seem similarly impotent in the face of the problems.' ${ }^{129}$

It is important that independent scientists, health professionals and professional bodies - in cooperation with human rights, civil liberties and whistleblowing organisations - promote the establishment of truly effective mechanisms under international and domestic law that provide legal protection against discrimination and criminal prosecution for whistleblowers. Furthermore, given the failings of the current systems of whistleblower protection, the life-science and biomedical communities have a duty to support those individuals who refuse to participate in what they consider immoral research and development projects, and those who blow the whistle on such activities. A number of scientific associations and professional bodies have mechanisms for promoting ethical standards amongst their members, which can also be utilised to support colleagues facing reprisals for acting ethically. ${ }^{130}$

\section{Conclusion}

In its public statement 'Preventing hostile use of the life sciences, from ethics and law to best practice', the ICRC has noted that '[a]dvances in the life sciences hold great promise for humanity', but that 'there is also great risk if these same advances are put to hostile use'. ${ }^{131}$ Whether the life sciences will be employed for the further development and proliferation of incapacitant weapons with the consequent dangers of the misuse of such weapons for internal repression or offensive military operations will depend to a significant degree on the actions of individual scientists and biomedical researchers and on the role of the life-science community as a whole. At a minimum this must entail stringent personal and community reflection and regulation of the trajectories

\footnotetext{
128 See, for example: Calland, R. and Dehn, G. (eds) 2004, Whistleblowing around the World, Open Democracy Advice Centre, Cape Town, \& Public Concern at Work, London; Deiseroth, op. cit.; Devine, T. 1997, The Whistleblower's Survival Guide, Fund for Constitutional Government, Washington, DC; Devine, T. 2004, 'Whistleblowing in the United States: the gap between vision and lessons learned', in Calland and Dehn, op. cit.; Martin, B. 1999a, 'Suppression of dissent in science', Research in Social Problems and Public Policy, vol. 7, pp. 105-35; Martin, B. 1999b, The Whistleblower's Handbook, Jon Carpenter, Charlbury, UK.

129 Martin, B. 2007, 'Whistle-blowing: risks and skills', in McLeish and Rappert, op. cit., p. 6.

130 For example, the AAAS Science and Human Rights Program (SHRP), which works with scientists to 'advance science and serve society' through human rights, has successfully campaigned on behalf of a number of scientific whistleblowers. For further information, see: $<$ http://shr.aaas.org/ $>$.

131 ICRC, 2004, op. cit.
} 
and possible applications of relevant research to ensure it cannot be used for hostile purposes. In addition, it can be argued that now is the time for the lifescience community to take a far more active and engaged stance on this issue and join with the arms control, disarmament, human rights and humanitarian law communities to explore the full range of voluntary, normative and legally binding mechanisms that can be applied to protect humanity from the potential of abuse of the relevant technologies they are developing, whilst preserving the beneficial applications. 